\title{
Preparation of isolated rat liver hepatocytes.
}

Quistorff, Bjørn; Dich, John; Grunnet, Niels

Published in:

Methods in Molecular Biology

Publication date:

1990

Document version

Publisher's PDF, also known as Version of record

Citation for published version (APA):

Quistorff, B., Dich, J., \& Grunnet, N. (1990). Preparation of isolated rat liver hepatocytes. Methods in Molecular Biology, Chapt 14, 151-160. 


\section{Chapter 14}

\section{Preparation of Isolated Rat Liver Hepatocytes}

\section{Bjørn Quistorff, John Dich, and Niels Grunnet}

\section{Introduction}

The bulk volume (about $85 \%$ ) of the mammalian liver parenchyma is contributed by the hepatocytes, whereas at least four other types of cells constitute the remainder (1). Procedures for the isolation of all five cell types have been described, although not from the sameliver. However, the isolation of hepatocytes has clearly been the most widely used preparation and has proved extremely valuable for a wide variety of experiments, spanning fields like pharmacokinetics, drug metabolism, and metabolic functions of the liver.

Historically two classes of methods have been used for the preparation of the isolated hepatocytes, either mechanical/chemical methods or enzymatic methods. The enzymatic techniques in which collagenase perfusion is applied as the principle of disintegration of the liver as first described by Berry and Friend (2) is completely dominating the field now and forms the basis of the method described in detail in this chapter. A number of symposia proceedings and reviews on the preparation and use of isolated hepatocytes have appeared (3-8). 
An added complication in the use of isolated hepatocytes is the demonstration in recent years of functional metabolic differences of hepatocytes of periportal and perivenous origin (for review, see 7). This chapter does not take such differences into account; however, a following chapter describes a method by which preparation of isolated hepatocytes, enriched in either periportal or perivenous cells, may be accomplished (this book, Chapter 16).

\section{Materials}

1. Adult Wistar rats weighing about $200 \mathrm{~g}$ were housed at $21^{\circ} \mathrm{C}$ with alternating 12-h cycles of light (7 $\mathrm{AM}-7 \mathrm{PM})$ and darkness.

2. Solution I: $118.0 \mathrm{mM} \mathrm{NaCl}, 4.7 \mathrm{mM} \mathrm{KCl}, 1.2 \mathrm{mM} \mathrm{KH}_{2} \mathrm{PO}_{4}$, and $25 \mathrm{mM}$ $\mathrm{NaHCO}_{3}$.

3. Solution II: As solution I plus $3 \mathrm{mMCaCl}, 1.2 \mathrm{mM} \mathrm{MgSO}_{4}$, and collagenase $(0.2-0.4 \mathrm{mg} / \mathrm{mL})$.

4. Solution III: As Solution II without collagenase. In order to avoid micro-floral contamination, all solutions were prepared from individual stock solutions 5 times more concentrated. Solutions were equilibrated with oxygen/carbon dioxide (19:1, vol/vol) for $1 \mathrm{~h}$ before use and kept in a thermostated waterbath at $39^{\circ} \mathrm{C}$ during the cell isolation procedure (Fig. 1). Because of heat loss in the tubing system, the perfusate temperature at the liver outlet is $34-35^{\circ} \mathrm{C}$.

5. Trypan blue solution: $0.5 \mathrm{~g}$ Trypan blue in $100 \mathrm{~mL}$ of buffer containing $140 \mathrm{mM} \mathrm{NaCl}, 4.7 \mathrm{mM} \mathrm{KCl}, 1.2 \mathrm{mM} \mathrm{KH}_{2} \mathrm{PO}_{4}, 0.6 \mathrm{mM} \mathrm{MgSO}_{4}$, and $10 \mathrm{~m} M$ HEPES, $\mathrm{pH}$ 7.4. The solution is stirred for $2 \mathrm{~h}$ and filtered. Aliquots can be preserved at $-18^{\circ} \mathrm{C}$.

6. Water bath: A conventional thermostated shaking water bath with an accuracy of $\pm 0.2^{\circ} \mathrm{C}$ and a stroke amplitude of about $2 \mathrm{~cm}$ is used.

7. Oxygenation: It is sufficient to bubble solutions with mounted Pasteur pipets connected to the oxygen/carbon dioxide tank (19:1, vol/ vol).

8. A two-channel roller pump (e.g., LKB 2115, LKB, Bromma, Sweden) is preferable. The pump should be able to give a variable flow rate of 20-40 $\mathrm{mL} / \mathrm{min}$.

9. Bubble trap: Since infusion of only small amounts of air is deleterious to the perfusion, it is highly advisable to mount a simple bubble trap on the infusion line.

10. Cannula: A glass cannula or a double cannula (19-gage $\times 1-3 / 4$ in [needle], 16-gage $1-1 / 4$ in [catheter]) can be used. The latter is easier to handle by unexperienced persons. 


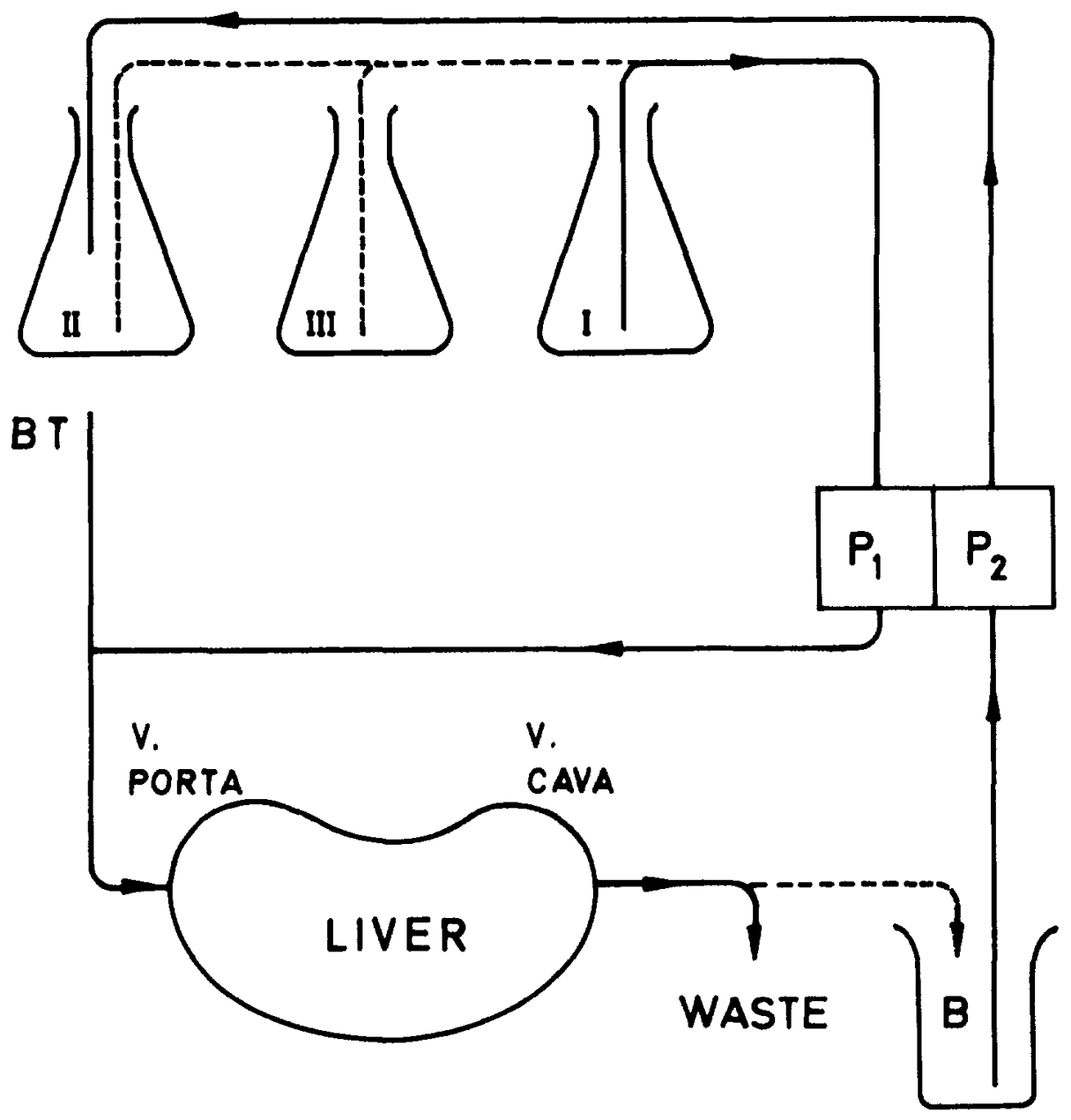

Fig. 1. Perfusion setup for preparation of isolated rat liver hepatocytes. The three solutions I, II, and III are kept in a thermostated water bath. P1, P2 is a two-channel roller pump. BT bubble-trap. B is a beaker for collection of effluent for recirculation during collagenase perfusion with perfusate II.

11. Filtration device: A simple but efficient filtration device consisting of a $250-\mathrm{mL}$ beaker, a Büchner funnel rubber gasket, and a nylon net (100 mesh $[160 \mu \mathrm{m}])$ is shown in Fig. 2.

12. Centrifuge: A conventional laboratory centrifuge equipped with a swing-out rotor can be used, provided that low $g$-values can be obtained reproducibly.

13. Tubing: Silastic tubing $4 \mathrm{~mm} / 2 \mathrm{~mm}$ o/i diameter was used. For cannulation of the superior caval vein, a $2-\mathrm{mm} / 1.5-\mathrm{mm}$ o/i diameter polyethylene catheter is used. 


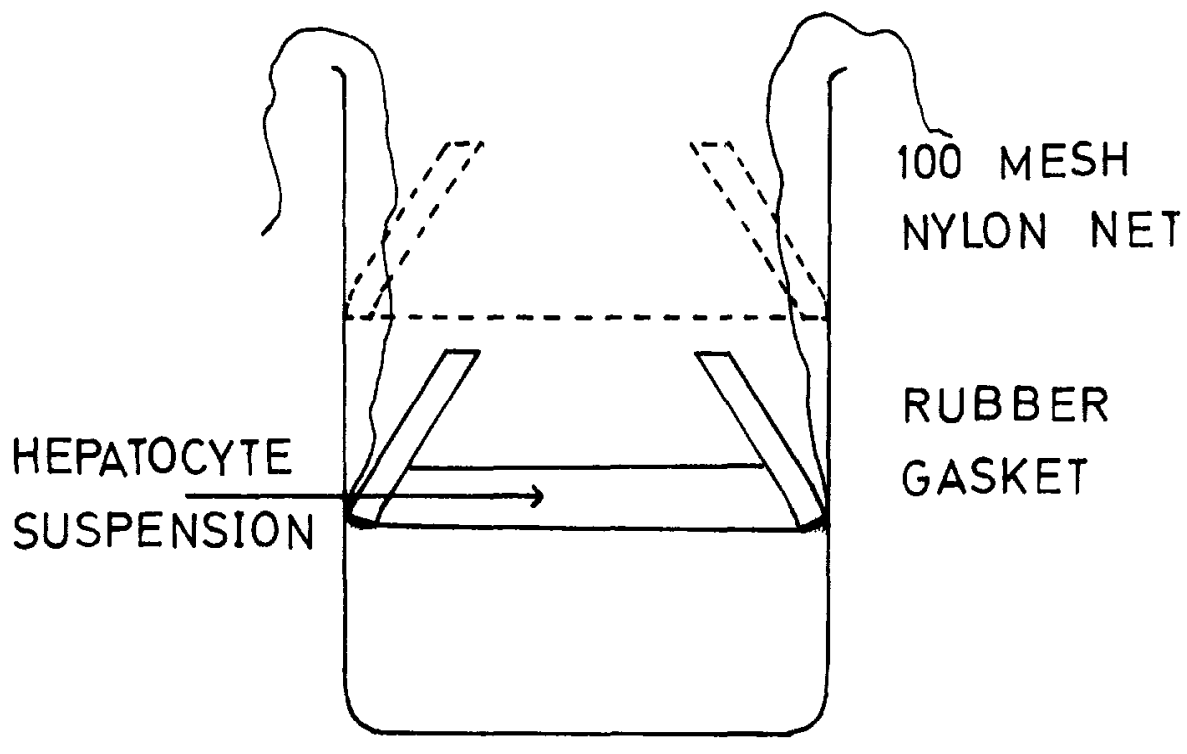

\section{$250 \mathrm{ml}$ BEAKER}

Fig. 2. Simple filtration device. The rubber gasket with the nylon net is pushed toward the bottom before the cell suspension is loaded on the net. The filtration is carried out by moving the gasket up and down a couple of times, if necessary, with addition of extra buffer.

14. Counting chamber: A conventional counting chamber with a volume of $0.1 \mu \mathrm{L}$.

15. Collagenase (type II) is used.

\section{Methods}

The essential features of the collagenase cell isolation procedure from rat liver involve five steps as listed in Table 1. Quantitative details of the procedure described below and in Table 1 refer to a rat weighing $200 \mathrm{~g}$. The procedure may, of course, be scaled to larger or smaller rats as required.

1. The liver of the anesthetized rat is perfused in situ via a cannulation of the portal vein. The abdomen is opened widely by a long midline incision and two perpendicular cuts at the level of the kidneys. The guts are moved to the left, out of the abdominal cavity, giving free access to the portal vein and the inf. v. cava. 
Table 1

Schematic Presentation of the Preparation of Isolated Rat Liver Hepatocytes

\begin{tabular}{|c|c|c|c|c|}
\hline Phase & $\begin{array}{l}\text { Perfusion/ } \\
\text { incubation }\end{array}$ & $\begin{array}{l}\text { Flow } \\
\mathrm{mL} / \mathrm{min}\end{array}$ & $\begin{array}{c}\text { Time } \\
\text { min }\end{array}$ & $\begin{array}{l}\text { Buffer/ } \\
\text { comment }\end{array}$ \\
\hline Phase 1 & $\begin{array}{l}\text { Calcium re- } \\
\text { moval }\end{array}$ & $35-40$ & $8-12$ & $\begin{array}{l}\text { Solution I } \\
\text { Flow- } \\
\text { through } \\
\text { perfusion }\end{array}$ \\
\hline Phase 2 & $\begin{array}{c}\text { Collagenase } \\
\text { perfusion }\end{array}$ & $20-30$ & $15-25$ & $\begin{array}{l}\text { Solution II } \\
\text { Recircula- } \\
\text { tion }\end{array}$ \\
\hline Phase 3 & $\begin{array}{l}\text { Rinse-cycle } \\
\text { perfusion }\end{array}$ & $35-40$ & $2-4$ & $\begin{array}{l}\text { Solution III } \\
\text { Flow- } \\
\text { through } \\
\text { perfusion }\end{array}$ \\
\hline Phase 4 & $\begin{array}{l}\text { Disintegration } \\
\text { of the liver, } \\
\text { followed by } \\
\text { incubation }\end{array}$ & - & 10 & $\begin{array}{l}\text { Incubation } \\
\text { with shaking } \\
(60-70 \\
\text { strokes / } \\
\text { min) in solu- } \\
\text { tion III }\end{array}$ \\
\hline Phase 5 & $\begin{array}{l}\text { Filtration and } \\
\text { cell separation }\end{array}$ & - & - & $\begin{array}{l}\text { Centrifugation } \\
3 \times 50 \mathrm{~g} \\
\times 2 \mathrm{~min}\end{array}$ \\
\hline
\end{tabular}

2. Prior to cannulation, ligatures are placed loosely around the $v$. porta (ca. $5 \mathrm{~mm}$ from the bifurcation to the different lobes), and around the v. cava inf. above the right kidney.

3. As soon as the cannula is in place in the portal vein and retrograde bleeding is observed, the ligature is tightened, the perfusion is started with perfusate I (see Fig. 1), and the inf. v. cava is cut open below the right kidney. The chest cavity is cut widely open, the v. cava sup. cannulated through the left atrium, and the ligature around v. cava inf. in the abdominal cavity is tightened.

4. Establishing the flow-through perfusion to this point usually takes a trained technician about 4-6 min. The liver must be homogenously 
bleached and absolutely without spots of unperfused areas. If that is not the case, the liver should be discarded. An additional interval of 8-12 min of perfusion with the calcium-free buffer is required to accomplish efficient calcium removal. Inefficient calcium removal will decrease cell yield drastically, since the cells will not separate properly.

5. The perfusate is switched to perfusate II (collagenase), and recirculation is established (see Fig. 1). The total perfusate volume at this time amounts to approximately $150 \mathrm{~mL}$.

6. The collagenase perfusion is usually continued for $15-25 \mathrm{~min}$ depending upon the appearance of the liver. With experience, it is possible to judge quite accurately from the appearance of the liver surface the degree of disintegration. One "semi-objective" indicator of sufficient collagenase perfusion is when a slight impression made (with the handle of a pair of tweezers) on the liver surface tends to remain. During collagenase perfusion, the perfusate starts to leak out through the liver surface, and in most experiments, $75-100 \%$ of the perfusate will be lost by the time when the collagenase treatment is sufficient. In a few experiments, it is necessary to prepare additional collagenase perfusate in order to complete the treatment.

7. The liver is now flushed for $3 \mathrm{~min}$ with perfusate III in a flow-through perfusion.

8. The perfusion is stopped, and the liver cut out and gently dispersed in a Petri dish with two forks in perfusate III.

9. The dispersed liver is incubated in a conical 1-L flask with a $\mathrm{O}_{2} / \mathrm{CO}_{2}$ atmosphere $(95 / 5 \mathrm{vol} \%)$ at $37^{\circ} \mathrm{C}$ for $10 \mathrm{~min}$ with gentle shaking $(60-70$ strokes/min).

10. The next step is filtering of the disintegrated liver through a nylon net. This may be accomplished as shown in Fig. 2. One should not try to force the liver cell suspension through the filter by mashing with a spoon or a spatula. Instead, the filter on the rubber ring may be moved up and down a couple of times and some extra medium may be added (see Table 1). A successful cell preparation at this stage is usually characterized by a remainder on the filter that constitutes mostly the fibrous vascular tree of the liver.

11. The final step consists of a separation of hepatocytes from cell debris and other smaller cells of the liver. This is accomplished by three lowspeed centrifugations ( $2 \mathrm{~min}$ at $50 \mathrm{~g}$ ) in two $30-\mathrm{mL}$ centrifuge tubes. The hepatocytes will sediment as a dark brown layer. Only these cells 
are useful, whereas debris and other cells, which will remain in the supernatant, are discarded. The centrifugation is repeated with two resuspensions of the cell pellet; the last time cells are pooled in a graduated tube in a medium to which is usually added 1-3\% bovine serum albumin. After the last centrifugation, the cells are suspended in the final buffer to be used in the particular experiment. The cell concentration here ranges from $2-10 \%$ in most experiments (see Notes $1-6)$.

\section{Notes}

1. With the procedure described above one routinely obtains a yield of 2-3 mL of packed cells corresponding to $2-4 \times 10^{8}$ cells, which is about $50 \%$ of the total hepatocyte population of the liver.

2. The most frequently used test of cell viability is Trypan blue staining. The test is carried out immediately after the final centrifugation by mixing $50 \mu \mathrm{L}$ of cell suspension with $50 \mu \mathrm{L}$ Trypan blue solution. The cell suspension is allowed to stand for $1 \mathrm{~min}$ prior to a 10-fold dilution with $0.9 \% \mathrm{NaCl}$, followed by examination in an hemocytometer (vol $0.1 \mu \mathrm{L}$ ). Several factors are observed in the light microscope at a magnification power of 40 :

a. The number of cells $/ 0.1 \mu \mathrm{L}$

b. The number of cells smaller than $10 \mu \mathrm{m}$

c. The appearance of the cells, rounded and with or without blebs

d. The number of hepatocytes that do not have blue stained nucleus. This number in percentages is referred to as the percentage of viable cells. More than 200 cells should be counted.

Usually $>90 \%$ of the cells obtained by the procedure described above exclude Trypan blue and show normal morphology, i.e., rounded cells without blebs of a size of 15-25 $\mu \mathrm{m}$. Less than 5\% nonhepatocytes are found in the preparation.

The criterion for positive Trypan blue staining is a visible blue nucleus. Unfortunately, there is no correlation between the percentage of stained cells and the metabolic capability of the isolated hepatocytes (9). Therefore, a number of other viability criteria have been suggested. Among these, the content of ATP is probably the easiest. ATP should be $>2 \mu \mathrm{mol} / 10^{8}$ cells. Also the capacity for glucose synthesis, the leak of cytosolic enzymes (LDH, ALAT), or the 
response in terms of oxygen consumption upon incubation with various substrates may be used (3,7-9). In the practical experiment, however, it is difficult to perform an extensive testing of the isolated cells prior to the experiment itself, since the cells tend to deteriorate in terms of metabolic capacity over about $2-3 \mathrm{~h}$. In terms of the viability test, the bottom line is "that anyone who proposes to work on isolated hepatocytes should satisfy himself that he can reproduce the maximum rates reported in the literature before studying new aspects. Merely looking at cells- at their shape and at dye exclusion-is not good enough. Nor is reproducibility of data, because this does not reveal systematic errors..." as stated by Krebs et al. (9).

3. Inclusion of hyaluronidase in the collagenase-containing perfusate (2), addition of EDTA to the calcium-free perfusate (10), the use of buffers other than Krebs-Henseleit bicarbonate, e.g., Hanks' solutions (11), higher concentrations of collagenase, inclusion of erythrocytes (12), and ex situ perfusion in thermostated perfusion cabinet are variations of the described technique, which have been used successfully, but without significant improvement over the simpler technique described here. Likewise, oxygenators are superfluous as long as the perfusion solutions are bubbled efficiently with $95 \% \mathrm{O}_{2} /$ $5 \% \mathrm{CO}_{2}$ (vol/vol). Thus, it appears that many details of the cell preparation procedure are uncritical and only a few essential factors may be identified. In our opinion, these are the quality of the liver perfusion, efficient depletion of calcium, and the presence of calcium in the collagenase solution.

Some authors recommend inclusion of DNase in the buffer used for incubation of the digested liver (phase 4, Table 1) to prevent clumping of the cells (13). Normally, however, clumping of the cells is not a problem.

For the purpose of comparison, it may be desirable to obtain a liver samplebefore the preparation of isolated cells. After the perfusion has been established, the small caudate lobe (next to the right kidney) can be ligated and cut off without affecting the remaining part of the procedure (14).

4. Isolated hepatocytes are usually incubated in conical flasks at $37^{\circ} \mathrm{C}$ at a concentration of $0.5-10 \times 10^{6}$ cells $/ \mathrm{mL}$, corresponding to approximately 4-70 $\mathrm{mg}$ wet $\mathrm{wt} . / \mathrm{mL}$ (15). Shaking of the flasks, 60-80 strokes $/ \mathrm{min}$, is necessary. With a gas phase of $95 \% \mathrm{O}_{2} / 5 \% \mathrm{CO}_{2}$, the depth of the suspension should not under these conditions exceed 6 $\mathrm{mm}$ in order to ensure proper oxygenation. Flasks equipped with a 
center well improve stirring of the cell suspension. Albumin (1-3\%) is often included in the final suspension medium and in the incubation medium. Unless fatty acids areincluded in the medium, there appears to be no beneficial effect of albumin on metabolic rates or on cell survival. The incubation time should bekept below $2 \mathrm{~h}$. Isolated hepatocytes may be used for primary cultures (this book, Chapter 15).

5. Isolated hepatocytes in suspension are able to carry out most intracellular processes at rates close to those attainable in the perfused liver. In some respects, however, isolated hepatocytes appear less competent. This is the case for glycogen synthesis, which is nonexistent in isolated hepatocytes unless special conditions prevail, i.e. high glucose concentrations $(>15 \mathrm{mM})$ or lactate $(5 \mathrm{mM})$, pyruvate $(1 \mathrm{mM})$ and glutamine $(10 \mathrm{mM})(16,17)$. Isolated hepatocytes are in a state of marked, negative nitrogen balance, which may be alleviated by the addition of amino acids to the incubation medium (18).

During preparation, the hepatocytes are depleted of low mol wt intermediates (3). Consequently, they are in an oxidized state (a state 2) (19) with substrate supply being rate-limiting for the respiratory chain and synthetic processes. Addition of lactate $(5 \mathrm{mM})$ plus pyruvate ( 1 $\mathrm{mM}$ ) appears adequate to establish a physiological NAD-redox level in the cytosolic and mitochondrial cell compartment and to supply precursors for, e.g., gluconeogenesis and fatty acid synthesis. Exogenous fatty acids results in a rather reduced NAD-redox state, unless lactate and pyruvate are added (20). Secretory processes, e.g., the secretion of albumin, occur at a rate comparable to that in perfused liver, but lower than in vivo (21).

6. The enzyme assays and metabolite assays employed in the evaluation of cell viability and functional capacity may be used directly as described, e.g., in the handbooks $(22,23)$.

\section{References}

1. Greengaard,O., Federman, M., and Knox, W. E. (1972) Cytomorphometry of developing rat liver and its application to enzyme differentiation. J. Cell Biol. 52, 261-272.

2. Berry, N. M. and Friend, D. S. (1969) High yield preparation of isolated rat liver parenchymal cells. J. Cell Biol. 43,506-520.

3. Krebs, H. A., Cornell, N. W., Lund, P., and Hems, R. (1974) Isolated liver cells as experimental material, in Regulation of Hepatic Metabolism. (Lundquist, F. and Tygstrup, N., eds.), Munksgaard, Copenhagen, pp. 726-750.

4. Seglen, P. O. (1976) Preparation of isolated rat liver cells, in Methods in Cell Biology, vol. 19 (Prescott, D. M., ed.), Academic, New York, pp. 29-83. 
5. Tager, J. M., Sölling, H. D., and Williamson,J.R. (eds.)(1976) Use of Isolated Liver Cells and Kidney Tubules in Metabolic Studies (Elsevier, Amsterdam).

6. Seglen, P. O. (1979) Disaggregation and separation of rat liver cells, in Cell Populations (Reid, E., ed.), Wiley, New York, pp. 25-46.

7. Thurman, R. G., Kauffman, F. C., and Jungermann, K. (eds.) (1986) Regulation of hepatic metabolism, in Inter- and Intra-Cellular Compartmentation (Plenum, New York).

8. Harris, R. A. and Cornell, N. W., eds. (1983) Isolation, Characterization, and Use of Hepatocytes (Elsevier Biomedical, Amsterdam).

9. Krebs, H. A., Lund, P., and Edwards, M. (1979) Criteria of metabolic competence of isolated hepatocytes, in Cell Populations (Reid, E., ed.), Wiley, New York, pp. 1-6.

10. Seglen, P. O. (1972) Preparation of rat liver cells. I. Effect of calcium on enzymatic dispersion of isolated perfused liver. Exp. Cell. Res. 74, 450-454.

11. Berg, T. and Merland, J. (1975) Induction of tryptophan oxygenase by dexamethasone in isolated hepatocytes. Dependence on composition of medium and $\mathrm{pH}$. Biochim. Biophys. Acta. 392, 233-241.

12. Quistorff, B., Bondesen, S., and Grunnet, N. (1973) Preparation and biochemical characterization of parenchymal cells from rat liver. Biochim. Biophys. Acta. 320, 503-516.

13. Bellemann, P., Gebhardt, R., and Mecke, D. (1977) An improved method for the isolation of hepatocytes from liver slices. Anal. Biochem. 81, 408-415.

14. Quistorff, B.(1986) Gluconeogenesis in periportal and perivenous hepatocytes of rat liver, isolated by a new high-yield digitonin/collagenase perfusion technique. Biochem. J. 229, 221-226.

15. Jurin, R. R. and McCune, S. A. (1985) Effect of cell density on metabolism in isolated rat hepatocytes. J. Cell. Physiol. 123, 442-448.

16. Katz, J., Golden, S., and Wals, P. (1976) Stimulation of hepatic glycogen synthesis by amino acids. Proc. Natl. Acad. Sci. 73, 3433-3437.

17. Boyd, M. E., Albright, E. B., Foster, D. W., and McGarry, J. D. (1981) In vitro reversal of the fasting state of liver metabolism in the rat. J. Clin. Invest. 68, 142-152.

18. Seglen, P.O., Gordon, P. B., and Poli, A. (1980) Amino acid inhibition of autophagic/ lysosomal pathway of protein degradation in isolated rat hepatocytes. Biochim. Biophys. Acta. 630, 103-118.

19. Chance, B. and Williams, G. R. (1955) Respiratory enzymes in oxidative phosphorylation. III. The steady state. J. Biol. Chem. 217, 409-427.

20. Berry, N. M., Grivell, A. R., and Wallace, P. G. (1980) Energy dependent regulation of the steady state concentration of the components of the lactate dehydrogenase reaction in the liver. FEBS Lett. 119, 317-322.

21. Dich, J. A. and Glud, C. N. (1976) Effect of glucagon on cyclic AMP, albumin metabolism and incorporation of ${ }^{14} \mathrm{C}$-leucine into proteins in isolated parenchymal rat liver cells. Acta. Physiol. Scand. 97, 457-469.

22. Bergmeyer, H. U. (1974) Methods of Enzymatic Analysis. 2nd English Ed. (Academic, New York).

23. Lowry, O. H. and Passonneau, J. V. (1972) A Flexible System of Enzymatic Analysis (Academic, New York). 